\title{
Responses of heterotrophic bacteria to solar irradiance in the eastern Pacific Ocean
}

\author{
J. Dean Pakulski ${ }^{1}$, Amy Baldwin ${ }^{1}$, Amanda L. Dean ${ }^{2}$, Sarah Durkin ${ }^{1}$, \\ Deneb Karentz ${ }^{3}$, Cheryl A. Kelley ${ }^{4}$, Kerry Scott ${ }^{1}$, Howard J. Spero ${ }^{5}$, \\ Steven W. Wilhelm ${ }^{2}$, Raid Amin ${ }^{6}$, Wade H. Jeffrey ${ }^{1, *}$ \\ ${ }^{1}$ Center for Environmental Diagnostics and Bioremediation, University of West Florida, Building 58, \\ 11000 University Parkway, Pensacola, Florida 32514, USA \\ ${ }^{2}$ Department of Microbiology, M409 WLS, University of Tennessee, Knoxville, Tennessee 37996, USA \\ ${ }^{3}$ Department of Biology, 2130 Fulton Street, University of San Francisco, San Francisco, California 94117-1080, USA \\ ${ }^{4}$ Department of Geological Sciences, 101 Geological Science Building, University of Missouri-Columbia, Columbia, \\ Missouri 65211, USA \\ ${ }^{5}$ Department of Geology, One Shields Avenue, University of California, Davis, California 95616-8605, USA \\ ${ }^{6}$ Department of Statistics, University of West Florida, Building 38, 11000 University Parkway, Pensacola, Florida 32514, USA
}

\begin{abstract}
We investigated the effects of sunlight on bacterial ${ }^{3} \mathrm{H}$-leucine (Leu) and ${ }^{3} \mathrm{H}$-thymidine (TdR) incorporation at 12 locations, from $41^{\circ} \mathrm{S}$ to $4^{\circ} \mathrm{N}$ in the eastern Pacific Ocean, during July and August 2000. Surface water samples amended with Leu and TdR were incubated under ambient sunlight using optical filters corresponding to the following wavebands: UVB+UVA+PAR, UVA+PAR, long-wavelength UVA+PAR, and PAR. Incorporation rates of Leu and TdR in dark controls were statistically compared to rates in the light treatments to determine the effect of solar irradiance on bacterial production at each station. We observed robust photo-stimulation of TdR incorporation with $\mathrm{UVA}+\mathrm{PAR}$ and long-UVA+PAR treatments at $17^{\circ} \mathrm{S}$ and in all light treatments at $13^{\circ} \mathrm{S}$. PAR stimulation of Leu incorporation occurred over much of the south to north survey. Bacterial community structure analyses indicated the presence of 4 communities that exhibited unique responses to ambient solar irradiance. Between $21^{\circ} \mathrm{S}$ and $4^{\circ} \mathrm{N}$, the $\delta^{13} \mathrm{C}$ of dissolved inorganic carbon $\left(\delta^{13} \mathrm{C}_{\mathrm{DIC}}\right)$ was significantly and inversely correlated with UVB, UVA, PAR, and dark Leu incorporation, but not to sea surface temperature, or concentrations of nitrate and chlorophyll. Our results demonstrate widespread direct dependence on solar irradiance, especially longer wavelengths, for bacterial production in surface water of the southeastern Pacific Ocean. Additionally, our data suggest that latitudinal trends in $\delta^{13} \mathrm{C}_{\mathrm{DIC}}$ are strongly associated with trends in solar UVB and bacterial production in upwelling waters, with implications for carbon cycling in tropical and subtropical waters.
\end{abstract}

KEY WORDS: Microbial diversity · Pacific Ocean · Ultraviolet radiation · Bacterioplankton

\section{INTRODUCTION}

Heterotrophic bacteria play a central role in the biogeochemistry and trophic dynamics of marine ecosystems (Goldman et al. 1985, Thingstad et al. 1993, Azam 1998, Tortell et al. 1999, Strom 2000). Concerns over stratospheric ozone depletion have stimulated research on the effects of ultraviolet radiation (UVR; $280-400 \mathrm{~nm})$ on the growth and metabolism of heterotrophic bacteria (see reviews by Harm 1980, Herndl 1997, Jeffrey et al. 2000, Moran \& Zepp 2000). Previous investigations, however, focused on processes operating on limited temporal (d) and spatial $\left(<1\right.$ to $\left.10 \mathrm{~km}^{2}\right)$ scales. These limitations have made the development of global-scale hypotheses and ecological forecasting models difficult (Jeffrey et al. 2000, Moran \& Zepp 2000). 
The intensity of UVR and photosynthetically-active radiation ( $\left.\mathrm{PAR}_{\mathbf{4}} 400-700 \mathrm{~nm}\right)$, and the ratio of UVB (280-320 nm) to UVA (320-400 nm) vary with latitude and season due to geographic variations in total column ozone concentrations and solar zenith angle (Whitehead et al. 2000). Less predictable short term (hourly) variations in solar irradiance are related to cloud cover and weather conditions. Latitudinal variation in solar irradiance may influence bacterial growth and metabolism directly (Vincent \& Neale 2000) or indirectly by affecting the production and availability of bacterial substrates derived from photochemical processes (Kieber 2000) and photosynthesis (Marañón et al. 2004). Viruses and heterotrophic nanoflagellates also contribute to mortality of bacteria, and are negatively impacted by solar radiation (Sommaruga et al. 1996, 1997, Wilhelm et al. 1998). Additionally, latitudinal and seasonal changes in irradiance influence surface water temperatures and water column stratification. Temperature may directly affect bacterial growth and metabolism (Pomeroy \& Wiebe 2001), whereas stratification may influence the depth of the mixed layer and primary production (Sverdrup 1953); thus, the general availability and distribution of bacterial substrates derived from photosynthesis. Therefore, direct and indirect effects of solar radiation may influence growth, metabolism, and community structure of surface dwelling bacteria over large latitudinal gradients.

Responses of bacteria to large-scale geographical variability in solar radiation have not been investigated previously. Here, we report results from a ship-of-opportunity cruise: Translatitudinal Assessment of Bacterial Acclimation to Solar Conditions in the Ocean (TABASCO), where we examined the effect of ambient solar radiation on bacteria in the southeastern Pacific Ocean during the austral winter.

\section{MATERIALS AND METHODS}

Sample collection. Sample collections and experiments were conducted aboard the RV 'Nathaniel. B. Palmer' from $41.18^{\circ} \mathrm{S}, 78.07^{\circ} \mathrm{W}$ to $4.05^{\circ} \mathrm{N}, 81.93^{\circ} \mathrm{W}$ from 24 July to 4 August 2000 (Fig. 1). The vessel was transporting waste materials from Palmer Station, Antarctica to Louisiana and was authorized to stop for sample collections for a total of $1 \mathrm{~h}$ each day and obtain CTD profiles in the morning and afternoon.
Hydrography and light measurements. CTD profiles $(<500 \mathrm{~m})$ were obtained twice daily $(\mathrm{N}=26), \sim 1 \mathrm{~h}$ before sunrise and 16:00 h local time at intervals of $\sim 2^{\circ}$ of latitude (Fig. 1). Continuous measurements of surface salinity and temperature along the entire southto-north transect were collected by a Seabird SBE21 underway CTD. Surface water $(3 \mathrm{~m})$ for deck incubation experiments, bacterial abundance and community structure, chlorophyll, nutrients, and $\delta^{13} \mathrm{C}_{\text {DIC }}$ analyses were collected in 10-1 Go-Flo bottles. Surface irradiance was measured continuously by a radiometer (GUV 511C, Biospherical Instruments). Integrated exposure values for UVB (305 nm), UVA (320 nm), long-UVA (380 nm), and PAR (400-700 nm) were estimated by summation of 1-min measurements during deck experiments. Daily integrated irradiances along the cruise track, reported by Wilhelm et al. (2003), were used to examine statistical relationships among physical, chemical, and biological properties in this study.

Water chemistry. Samples for inorganic nutrients $(\mathrm{N}=23)$ were collected in polyethylene bottles rinsed with $10 \% \mathrm{HCl}$, Milli-Q water, and sample water. Samples were frozen $\left(-80^{\circ} \mathrm{C}\right)$ immediately after collection. Nutrient concentrations were measured after the cruise by automated methods (US Environmental Protection Agency 1983). Samples for $\delta^{13} C_{\text {DIC }}$ analyses $(N=24)$

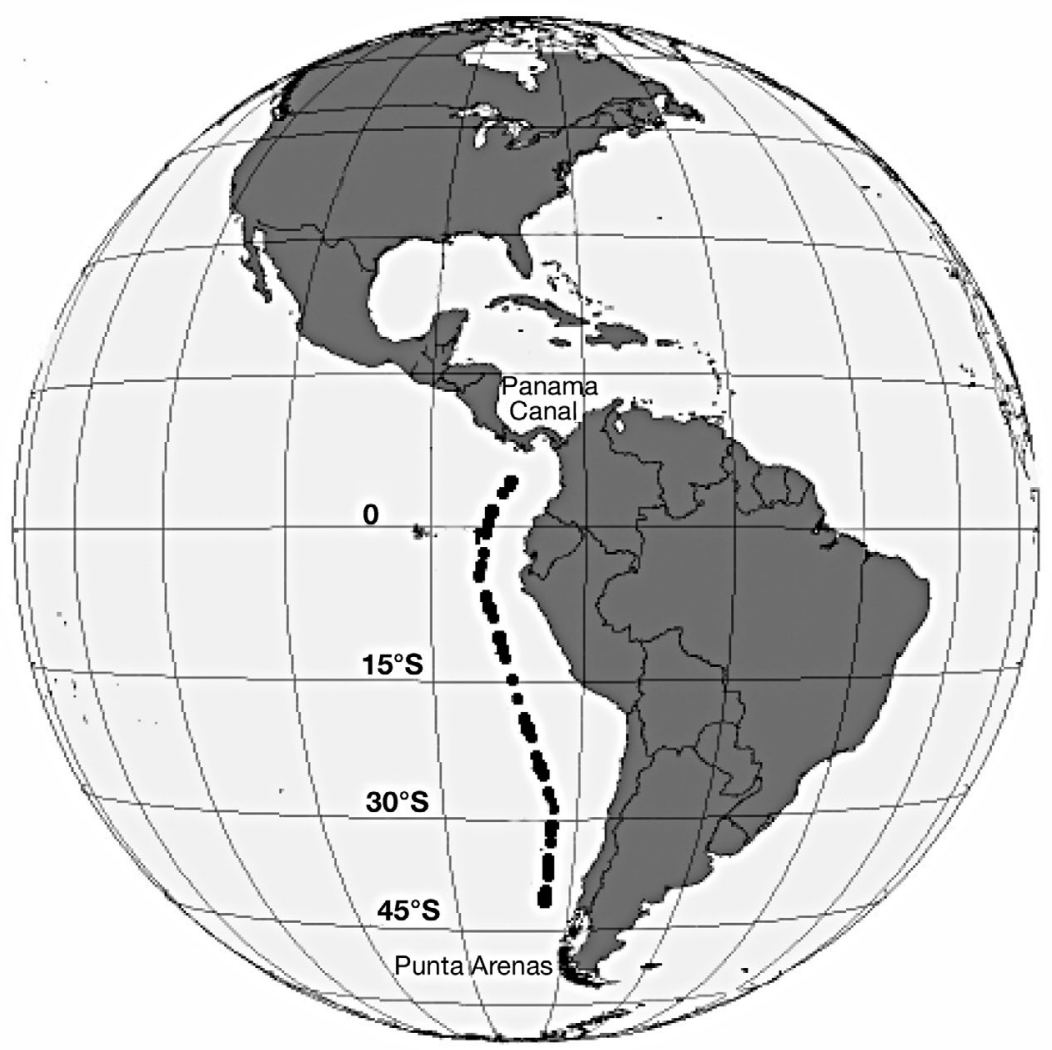

Fig. 1. TABASCO cruise track and location of the sampling stations 
were poisoned with $\mathrm{HgCl}_{2}$ and stored in airtight vials. Subsamples $(5 \mathrm{ml})$ were later acidified in vacuo with $\sim 0.5 \mathrm{ml}$ of purified ortho-phosphoric acid. Carbon isotope values of the evolved $\mathrm{CO}_{2}$ gas were measured with an isotope-ratio mass spectrometer (Micromass Optima). Data are presented in standard $\delta$ notation as the per mil (\%) difference from the Pee Dee Belemnite standard (Hut 1987). The analytical precision of the measurements was $\pm 0.08 \%(2 \sigma)$ determined by replicate analyses of a laboratory water standard.

Chlorophyll, bacterial abundances, and community structure. Chlorophyll samples $(\mathrm{N}=23)$ were collected on GF/F filters, extracted in $90 \%$ acetone, and quantified fluorometrically (Welschmeyer 1994) against spinach chlorophyll a standards (Sigma) and acid-corrected for phaeopigments. Bacterial cell concentrations ( $\mathrm{N}=23$ ) were measured by epifluorescence microscopy of formalin-preserved $(2 \%$ final concentration, stored at $4^{\circ} \mathrm{C}$ until returned to home institution) DAPI-stained samples (Porter \& Feig 1980). Samples for bacterial community structure (morning samples only, $\mathrm{N}=12$ ) were collected by filtration of $\sim 0.5$ to $1.0 \mathrm{l}$ seawater through $47 \mathrm{~mm}$, $0.2 \mu \mathrm{m}$ nominal pore-size filters (Gelman Supor). The filters were frozen and stored at $-80^{\circ} \mathrm{C}$ prior to phenol-chloroform extraction of bacterial DNA. Bacterial community structure was determined using Denaturing Gradient Gel Electrophoresis (DGGE; Murray et al. 1998) of PCR amplified bacterial 16S rDNA. Variable region 3 of the 16S rRNA gene (Neefs et al. 1990) was amplified by PCR with primer sequences complimentary to positions 341 to 358 (primer 358f; eubacterial) and positions 517 to 534 (primer $517 \mathrm{r}$; universal) corresponding to Escherichia coli 16S rRNA numbering (Muyzer et al. 1993). A 40-bp G-C clamp was added to the 358f primer. The primer sequences were 5'-CGC CCG CCG CGC GCG GCG GGC GGG GCG GGG GCA CGG GGG GCC TAC GGG AGG CAG CAG-3' for GC358f and 5'-ATT ACC GCG GCT GCT GG-3' for UNIV517r. Primers were obtained from Operon Technologies. DGGE was performed using the Dcode $^{\mathrm{TM}}$ Universal Mutation Detection System (Bio-Rad Laboratories). Gel electrophoresis banding patterns were used to generate dendrograms of bacterial community similarity, using an image analysis program (Gel Compar II Image Software, Applied Maths) using the UPGMA method and presence or absence, but not intensity, of bands.

Deck incubation experiments. Water samples $(\mathrm{N}=$ 12) were collected at dawn and held in the dark at ambient seawater temperature for $\sim 4 \mathrm{~h}$ prior to incubation on deck. Aliquots of sample water $(75 \mathrm{ml})$ were amended with ${ }^{3} \mathrm{H}$-leucine or ${ }^{3} \mathrm{H}$-thymidine (final concentrations $10 \mathrm{nM}$ ). Subsamples consisting of $5-\mathrm{ml}$ amended water were subsequently dispensed into UV- transparent bags (Whirl-pak ${ }^{\mathrm{TM}}$, NASCO; Aas et al. 1996) to insure uniform labeling between treatments. Duplicate Leu and TdR amended Whirl-pak bags were placed under glass optical filters (Schott) with 50\% cut-off wavelengths of 280, 320, 370, and $395 \mathrm{~nm}$ in an outdoor, flowing seawater bath. The filters allowed exposure to the following wavebands: UVB+UVA+ PAR (280 nm filter), UVA+PAR (320 nm filter), long wavelength UVA+PAR (370 nm filter), and PAR (395 nm filter). Duplicate, dark and formalin-killed controls were incubated in the bath with the lighttreatment samples. Samples were incubated for a total of $4 \mathrm{~h}$ : $\sim 2 \mathrm{~h}$ before and after local solar noon while the ship was underway. Leu and TdR incorporation was measured by the micro-centrifuge method (Smith \& Azam 1992). Dunnett's Test was used to determine statistically significant $(p<0.05)$ differences in rates between incorporation in the dark and light treatments. Where significant differences were observed between the light and dark treatments, the percent change in incorporation rates of Leu and $\mathrm{TdR}$, relative to the dark controls, was determined as:

$$
\begin{gathered}
\text { Percent change from dark }=[1-(\text { light rate } \div \\
\text { dark rate })] \times 100
\end{gathered}
$$

Negative values indicate inhibition, whereas positive values indicate stimulation. Where differences between light and dark treatments were not significant, the percent change from dark controls was assigned a value of zero.

\section{RESULTS}

\section{Surface irradiance, temperature, salinity, and water chemistry}

Integrated 305, 320, $380 \mathrm{~nm}$ irradiance, and PAR, measured during deck experiments, increased from $41^{\circ}$ to $9^{\circ} \mathrm{S}$ and declined northward across the equator (Fig. 2A). Surface water temperatures and salinities increased between $41^{\circ}$ and $5^{\circ} \mathrm{S}$ (Fig. 3A). From $5^{\circ} \mathrm{S}$ to north of the equator, temperatures increased and salinities decreased. Surface $\delta^{13} \mathrm{C}_{\text {DIC }}$ remained relatively constant $\left(\sim 1.7 \%\right.$ o) between $41^{\circ}$ and $21^{\circ} \mathrm{S}$, decreased to $-0.32 \%$ at $4^{\circ} \mathrm{S}$ and then increased to $1.59 \%$ at $4^{\circ} \mathrm{N}$ (Fig. 2B). Between $33^{\circ}$ and $15^{\circ} \mathrm{S}$ and north of $3^{\circ} \mathrm{S}$, nitrate concentrations were below the limit of detection (Fig. 3C). High concentrations of nitrate at the surface between $13^{\circ}$ and $3^{\circ} \mathrm{S}$ suggest that nutrient-rich water from the Peruvian Upwelling was present (Fig. 3C). At $4^{\circ}$ intervals between $21^{\circ} \mathrm{S}$ and $3^{\circ} \mathrm{N}$, correlation analyses (CORR procedure, SAS) indicated significant inverse relationships between $\delta^{13} \mathrm{C}_{\text {DIC }}$ and daily integrated 305, 320, $380 \mathrm{~nm}$ and PAR irradiance, 

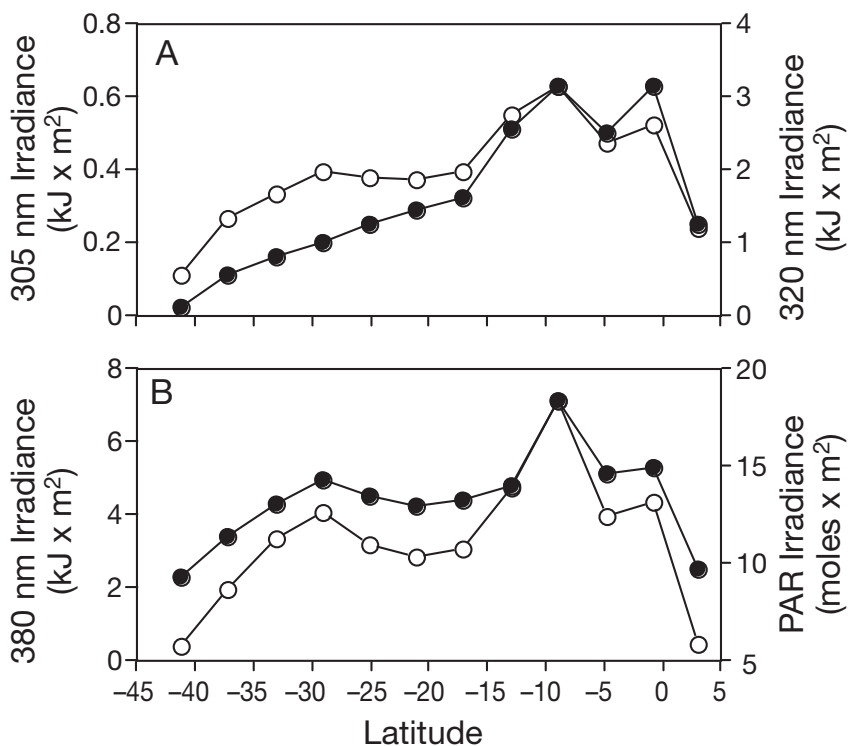

Fig. 2. Latitudinal trends in experimental light exposures (A) $305 \mathrm{~nm}$ irradiance (๑), $320 \mathrm{~nm}$ irradiance (O), and (B) 380-nm irradiance (๑), PAR (O)
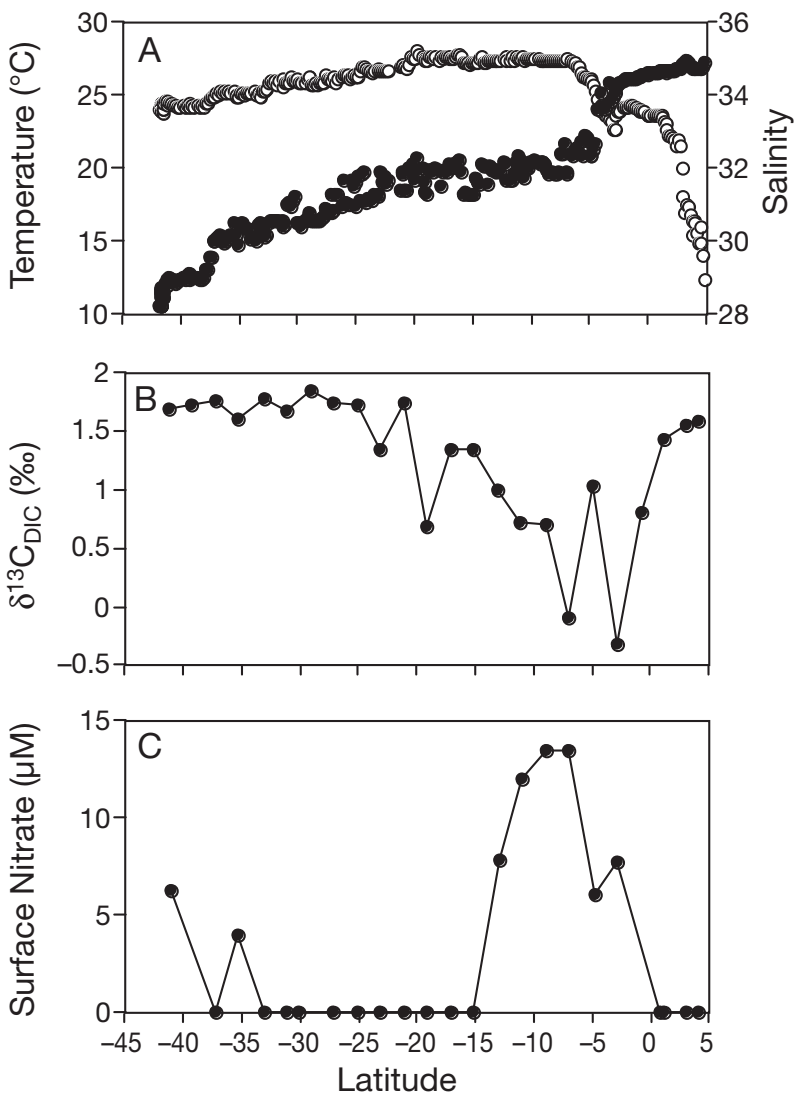

Fig. 3. Latitudinal trends in (A) surface temperature (๑) and salinity (O), (B) dissolved inorganic $\delta^{13} \mathrm{C}$, and (C) surface concentrations of nitrate and dark Leu incorporation (Table 1). At $2^{\circ}$ intervals in the high nitrate zone between $13^{\circ}$ and $3^{\circ} \mathrm{S}, \delta^{13} \mathrm{C}_{\text {DIC }}$ values were negatively correlated with sea surface temperatures $(r=-0.84, p=0.03)$, but were not significantly correlated with nitrate, chlorophyll $a$, or abundance of bacteria.

\section{Chlorophyll and bacterial production}

Concentrations of chlorophyll a were elevated at the southern end of the survey and declined between $29^{\circ}$ and $25^{\circ} \mathrm{S}$ (Fig. 4A). Chlorophyll concentrations were highest at $13^{\circ} \mathrm{S}$, afterward decreasing steadily across the equator. Surface bacterial concentrations were elevated at the southern end of the survey and were highest at $13^{\circ} \mathrm{S}$ (Fig. 4A). Similar to the trend in chlorophyll, bacterial abundances declined from $9^{\circ} \mathrm{S}$ to $4^{\circ} \mathrm{N}$. Bacterial production was low and relatively constant between $41^{\circ}$ and $17^{\circ} \mathrm{S}$ (Fig. 4B) and increased $\sim 5$-fold by $13^{\circ} \mathrm{S}$ and, in general, declined northward across the equator.

\section{Deck incubation experiments}

We observed no effect of ambient sunlight on Leu incorporation in UVB+UVA+PAR treatments between $41^{\circ}$ and $17^{\circ} \mathrm{S}$ and between $2^{\circ} \mathrm{S}$ and $3^{\circ} \mathrm{N}$ (Fig. $4 \mathrm{C}$ ). However, Leu incorporation was inhibited in UVB+UVA+PAR treatments at $9^{\circ}$ and $5^{\circ} \mathrm{S}$. Stimulation of Leu incorporation in UVA+PAR treatments occurred at $29^{\circ} \mathrm{S}, 21^{\circ} \mathrm{S}$, $13^{\circ} \mathrm{S}$, and $3^{\circ} \mathrm{N}$ and inhibition of Leu incorporation occurred in UVA+PAR treatments only at $5^{\circ} \mathrm{S}$. Stimulation of Leu incorporation in long-UVA+PAR occurred be-

Table 1. Correlations between $\delta^{13} \mathrm{C}_{\text {DIC }}$ and physical, chemical, and biological variables between $21^{\circ} \mathrm{S}$ and $3^{\circ} \mathrm{N} ; 29$ July to 4 August 2000. $\mathrm{N}=7$ stations. Daily-integrated radiation data are from Wilhelm et al. (2003). All other variables are from the present study

\begin{tabular}{|lcc|}
\hline Comparison & $\begin{array}{c}\delta^{13} \mathrm{C}_{\mathrm{DIC}} \\
\text { Pearson correlation } \\
\text { coefficient } \\
\mathrm{r}\end{array}$ & \\
\hline Daily integrated 305 nm & -0.97 & 0.0003 \\
Daily integrated 320 nm & -0.90 & 0.005 \\
Daily integrated 380 nm & -0.85 & 0.01 \\
Daily integrated PAR & -0.82 & 0.02 \\
Dark Leu incorporation & -0.75 & 0.049 \\
Dark TdR incorporation & -0.63 & 0.12 \\
Surface chlorophyll & -0.68 & 0.08 \\
Bacterial cell abundance & -0.14 & 0.76 \\
Surface temperature & 0.05 & 0.91 \\
\hline
\end{tabular}



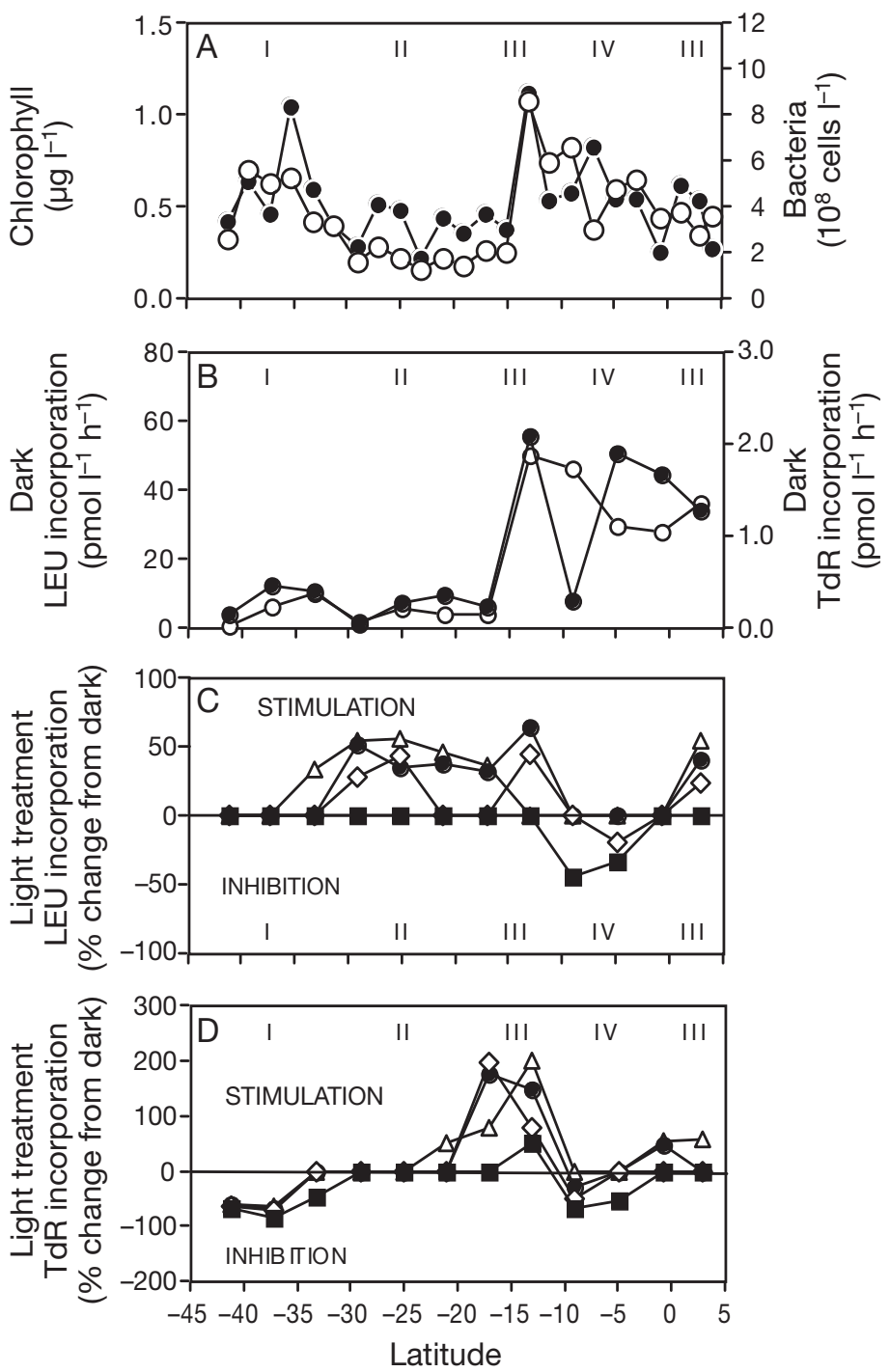

Fig. 4. Latitudinal trends in (A) concentrations of surface chlorophyll a (O) and bacterial cells (@), (B) dark treatment Leu (@) and TdR (O) incorporation, (C) light treatment for Leu incorporation during experimental exposure to UVB+ UVA+PAR $(\boldsymbol{\square})$, UVA+PAR $(\diamond)$, long wavelength UVA+PAR $(\bullet)$, and PAR $(\triangle)$, (D) light treatment TdR incorporation (symbols same as C). Roman numerals indicate approximate locations of bacterial communities identified by DGGE (see Fig. 7)

tween $29^{\circ}$ and $13^{\circ} \mathrm{S}$ and at $3^{\circ} \mathrm{N}$ and PAR treatments between $33^{\circ}$ and $17^{\circ} \mathrm{S}$ and $3^{\circ} \mathrm{N}$. Inhibition of Leu incorporation was not measured in long-UVA+PAR and PAR-only treatments at any station.

TdR incorporation was inhibited in all light treatments between $41^{\circ}$ and $37^{\circ} \mathrm{S}$ (Fig. 4D) and stimulated in all light treatments at $13^{\circ} \mathrm{S}$ (Fig. 5D). TdR incorporation in UVB+UVA+PAR treatments was inhibited between $41^{\circ}$ and $33^{\circ} \mathrm{S}$ and was not significantly different from dark treatment rates between $29^{\circ}$ and $17^{\circ} \mathrm{S}$. North of $13^{\circ} \mathrm{S}$, latitudinal trends of TdR incorporation in UVB+UVA+PAR treatments were similar to Leu incorporation in UVB+UVA+PAR treatments. With the exception of stimulation at $1^{\circ} \mathrm{S}$ in the long-UVA+PAR treatment, latitudinal trends in TdR incorporation from $\mathrm{UVA}+\mathrm{PAR}$ and long-UVA+PAR treatments were similar throughout the survey.

Between $41^{\circ}$ and $13^{\circ} \mathrm{S}$, there was a significant positive correlation between the PAR treatment for TdR incorporation and experimental PAR dose (Fig. 5A); however, there was a stronger correlation between the PAR treatment for TdR incorporation and daily, integrated PAR over this same interval (Fig. 5B). Between $25^{\circ}$ and $13^{\circ} \mathrm{S}$, a significant negative correlation ( $\mathrm{r}=$ 0.96, $p=0.02$ ) occurred between daily-integrated PAR and PAR treatment for Leu incorporation and a significant positive correlation $(r=0.95, p=0.03$ ) between daily-integrated PAR and PAR treatment for TdR incorporation (Fig. 6).

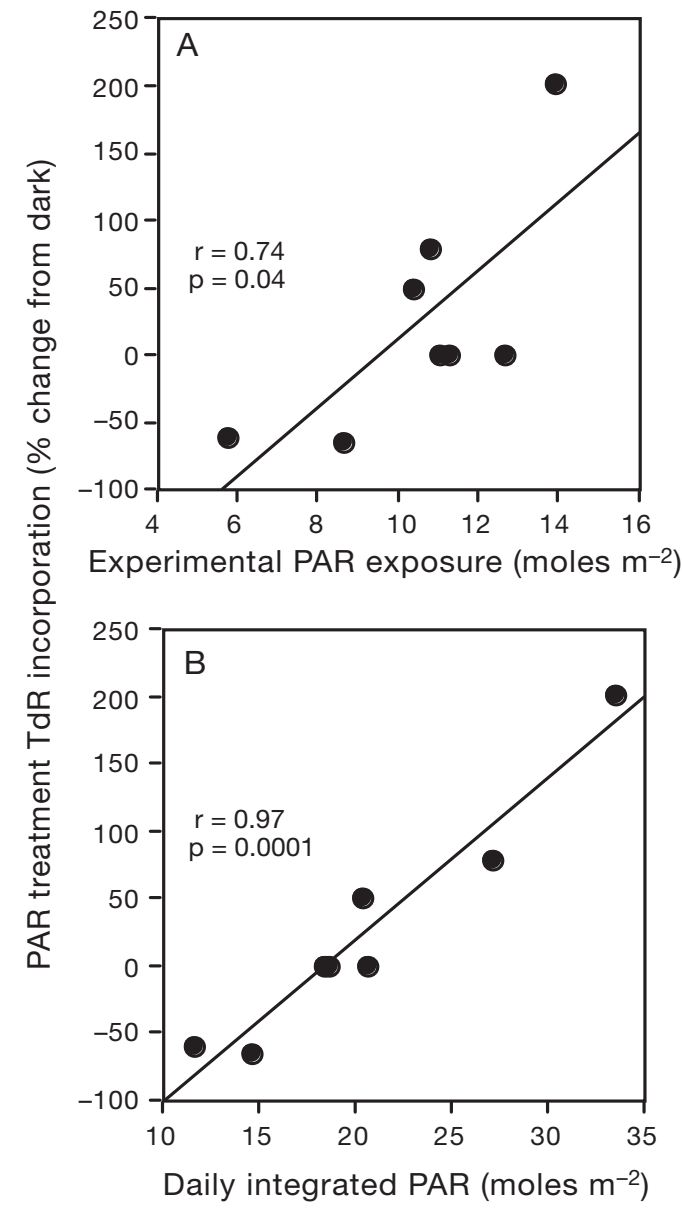

Fig. 5. (A) PAR treatment for $\mathrm{TdR}$ incorporation relative to dark rates and experimental PAR irradiances. (B) PAR treatment $\mathrm{TdR}$ incorporation relative to dark rates and dailyintegrated PAR irradiances, $41^{\circ}$ to $13^{\circ} \mathrm{S}$. Positive values = stimulation relative to dark rates, negative values $=$ inhibition relative to dark rates $(\mathrm{N}=8)$ 


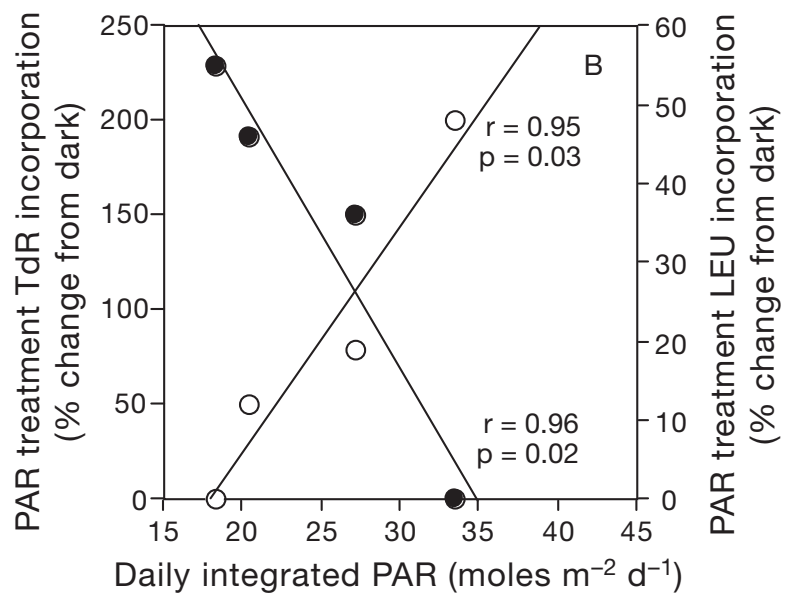

Fig. 6. Relationship between PAR treatment Leu (@) and $\mathrm{TdR}(\mathrm{O})$ incorporation and daily integrated PAR irradiance, $25^{\circ}$ to $13^{\circ} \mathrm{S}(\mathrm{N}=4)$

\section{Bacterial community structure}

DGGE analyses suggested that 4 broadly similar (>75\% similarity) assemblages of bacteria were present along the survey route (Fig. 7). The southernmost communities (Group 1) were present from $41^{\circ}$ to $34^{\circ} \mathrm{S}$ in cool $\left(\sim 10-17^{\circ} \mathrm{C}\right)$ surface water. Group 2 communities were present from $29^{\circ}$ to $21^{\circ} \mathrm{S}$ in $18-20^{\circ} \mathrm{C}$ water. Group 3 communities were present from $17^{\circ}$ to $13^{\circ} \mathrm{S}$ and at $1^{\circ} \mathrm{S}$ to $3^{\circ} \mathrm{N}$, at the southern and northern boundaries of high nitrate waters located between $13^{\circ}$ and $3^{\circ} \mathrm{S}$. Group 4 communities were present in warm surface waters, $20-25^{\circ} \mathrm{C}$, between $9^{\circ}$ and $5^{\circ} \mathrm{S}$. Each community exhibited unique responses to ambient surface irradiance. Group 1 exhibited inhibition of TdR incorporation in all light treatments, whereas Leu incorporation was insensitive to exposure to ambient UVR and PAR. Incorporation of Leu was stimulated in Group 2 by PAR and Leu and TdR incorporation were not inhibited by ambient UVB, UVA, or PAR. Group 3 communities exhibited PAR stimulation of both Leu and TdR incorporation and were not inhibited by exposure to UVR. UVR inhibited Leu and TdR incorporation in Group 4 and Leu and TdR incorporation were not stimulated in any light treatment.

\section{DISCUSSION}

Heterotrophic bacteria exhibited a wide range of responses to ambient solar irradiance along the cruise track. At $41^{\circ} \mathrm{S}$ and $37^{\circ} \mathrm{S}$, TdR incorporation was inhibited at all light treatments. The similarity of response among all light treatments indicated that PAR was primarily responsible for the inhibition of nucleic acid synthesis at these stations. Inhibition of TdR incorporation by UVR and PAR was previously reported in the Gulf of Mexico (Aas et al. 1996) and the Adriatic Sea (Sommaruga et al. 1997). Whereas UVR appears to inhibit bacterial growth by damage to DNA (Herndl 1997, Jeffrey et al. 2000, Moran \& Zepp 2000), mechanisms responsible for PAR inhibition of bacterial production remain obscure. Morán et al. (2001) proposed that apparent PAR inhibition of Leu incorporation in Mediterranean surface waters was a result of artificial
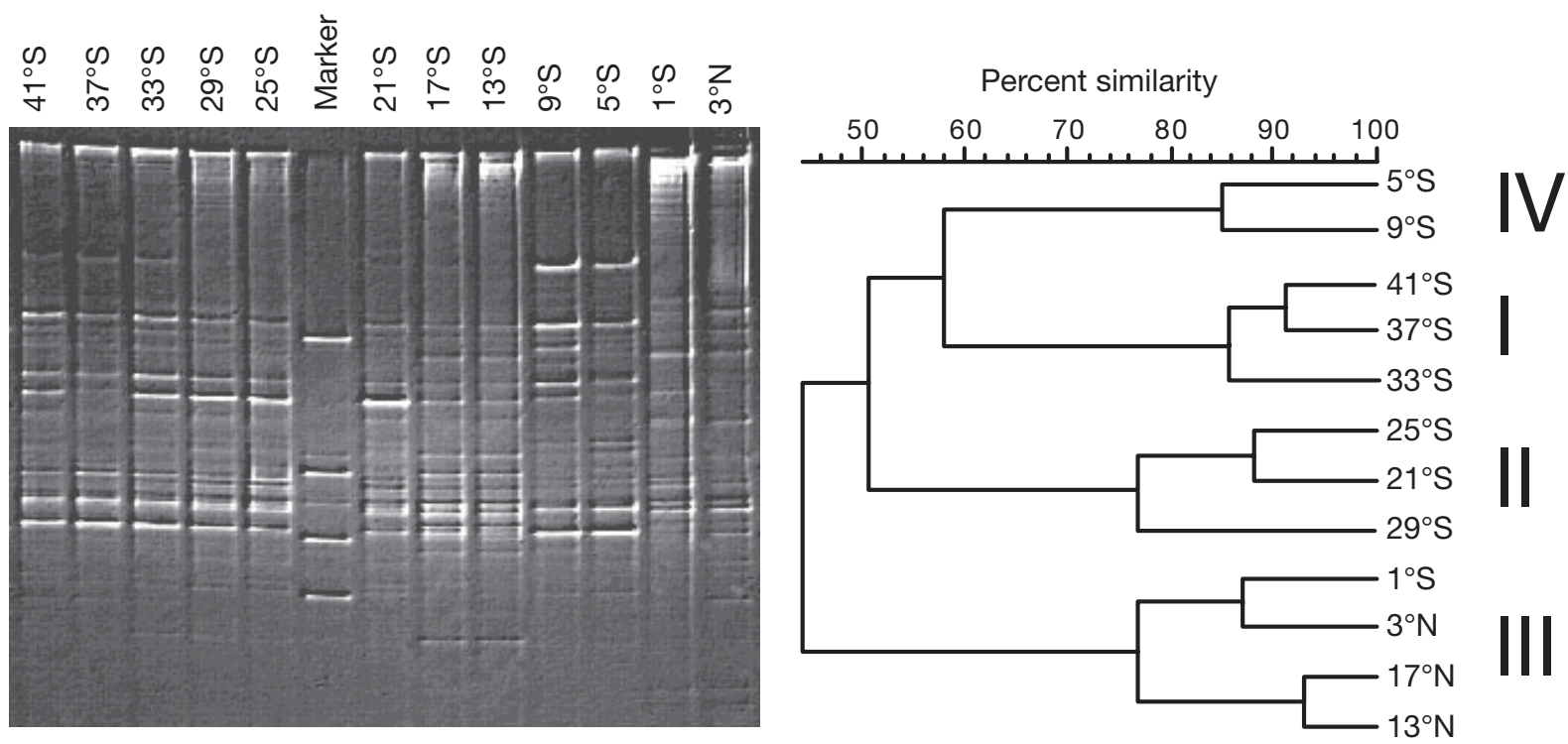

Fig. 7. Latitudinal trends in transect bacterial community structure visualized by banding patterns of bacterial 16S rDNA fragments after denaturing gradient gel electrophoresis and a similarity dendrogram of bacterial communities along survey route, based on DGGE analyses 
stimulation of bacterial growth in the dark. However, mechanisms that could stimulate bacterial growth in the dark have not been identified. Marañón et al. (2004) reported that release of DOC by phytoplankton is a light-dependent process that ceases in the dark. Sommaruga et al. (1996) reported that exposure to UVR reduced bacterivory by nanoflagellates. Bacterivory in dark controls might be enhanced relative to light treatment rates and potentially reduce incorporation rates of Leu and TdR in the dark. We observed no effect of UVR or PAR on Leu incorporation at $41^{\circ}$ and $37^{\circ} \mathrm{S}$. It is unlikely that artificial stimulation of bacterial growth in our dark controls can account for PAR inhibition of TdR incorporation that we observed at $41^{\circ}$ and $37^{\circ} \mathrm{S}$ or stimulation by sunlight of Leu and TdR incorporation that we observed elsewhere along the survey. We could not determine whether this inhibition was a direct or indirect effect of exposure to PAR.

In contrast to the 2 southernmost sample sites, we observed no significant effects of UVR on TdR incorporation between $29^{\circ}$ and $21^{\circ} \mathrm{S}$. This suggested that TdR incorporation at these locations was insensitive to ambient surface intensities of UVR at these latitudes and season. However, TdR incorporation was stimulated by exposure to UVA and PAR at $17^{\circ} \mathrm{S}$ and UVB, UVA, and PAR at $13^{\circ} \mathrm{S}$. Stimulation of TdR incorporation in natural bacterial communities exposed to ambient sunlight has not been reported. A number of mechanisms may be responsible for stimulation of nucleic acid synthesis at these localities. Chlorophyll concentrations peaked at $13^{\circ} \mathrm{S}$ along the survey. PARstimulated release of DOC from phytoplankton (Zlotnik \& Zobinsky 1989) may have enhanced substrate availability and growth-related nucleic acid synthesis in this region. Sommaruga et al. (1996) proposed that UVR-inhibition of nanoflagellate bacterivory resulted in a positive feedback between UVB exposure and bacterial production. Inhibition of protistan bacterivory in light treatments, relative to dark controls, may also have contributed to the apparent UVR stimulation of TdR incorporation in these 2 sampling areas. According to Ögrünç et al. (1998), bacterial and archeal nucleotide excision repair of UVR-induced CPD or 6-4 photoproducts results in the excision and subsequent polymerization of 10-13 nucleotide oligomers at each repair site. Exogenous TdR could be incorporated into UVR-damaged DNA and contribute to incorporation of TdR. Church et al. (2004) proposed that Prochlorococcus at station ALOHA were responsible for light-stimulated incorporation of leucine. Cyanobacteria can incorporate amino acids (Zubkov et al. 2003), but lack thymidine kinase (http://cyano.genome.jp), the enzyme essential for incorporation of exogenous TdR (Kornberg 1980). It is unlikely that cyanobacteria were responsible for the light-stimulated of TdR incorpora- tion that we observed at $13^{\circ} \mathrm{S}$. The greatest stimulation of TdR incorporation occurred in the PAR treatment, followed by the long wavelength-UVA+PAR, UVA+ $\mathrm{PAR}$, and UVB+UVA+ PAR treatments. This indicated that the net stimulatory effect of exposure to PAR diminished with increasing exposure to UVA and UVB. Photo-inhibition of DOC release from phytoplankton or an increase in the rate of DNA damage relative to the rate of DNA repair may account for reduced TdR incorporation with increasing exposure to the shorter wavelengths of UVR at $13^{\circ} \mathrm{S}$.

Light stimulation of Leu incorporation was observed through most of the survey. PAR and UVA+PAR were responsible for most of this stimulatory effect. PAR simulation of prokaryotic Leu incorporation has been reported from the Mediterranean and North Pacific Oceans (Morán et al. 2001, Church et al. 2004, AlonsoSáez et al. 2006). Recent research suggested that photoheterotrophy is widespread in temperate and tropical surface waters and contributes to bacterial production in marine surface water (Béjà et al. 2000, Kolber et al. 2000, 2001, Zubkov et al. 2003). In our study, we could not determine whether photo-stimulated Leu incorporation was solely the result of bacterial photoheterotrophy. Other factors, such as lightenhanced release of DOC from phytoplankton and photolysis of DOC, might contribute to light-stimulated incorporation of Leu. As photo-stimulation of Leu incorporation was greatest in the long wavelength $\mathrm{UVA}+\mathrm{PAR}$ and PAR treatments, PAR-mediated biological, rather than UVR-mediated photochemical processes might have played a greater role in photo-stimulation of Leu and TdR incorporation by bacteria in our deck experiments. Many of our results were unexpected. The majority of studies reported that exposure to full UVR inhibits bacterial production (Herndl et al. 1993, Aas et al. 1996, Sommaruga et al. 1997, Pakulski et al. 1998). At several of the sampling locations, apparent photo-stimulation by longer wavelengths was great enough to offset the inhibitory effects of UVR on bacterial production.

Community structure may play a critical role in determining bacterioplankton response to solar radiation. Van Mooy et al. (2004) reported that bacterial community structure in the eastern Subarctic Pacific was strongly and independently related to geographical trends in PAR and primary production. AlonsoSáez et al. (2006) recently reported differences in photo-sensitivity of different bacterioplankton groups in the Mediterranean Sea. In our study, latitudinal trends in light treatment of Leu and TdR incorporation also corresponded to shifts in community structure.

Photo-responses of Group 3 communities were similar despite geographical separation. These communities were located at the northern and southern bound- 
aries of high-nitrate water associated with the Peruvian Upwelling. Baldwin et al. (2005) reported the development of genetically similar bacterial communities to the north and south of the Equatorial Upwelling in the central Pacific. Exposure experiments indicated that those communities exhibited similar responses to ambient solar irradiance (J. D. Pakulski et al. unpubl.), and that bacterial communities developing under similar environmental conditions, but separated geographically, exhibit similar responses to solar irradiance.

Light treatment for Leu and TdR incorporation varied with latitudinal trends in insolation. From $41^{\circ}$ to $13^{\circ} \mathrm{S}$, the PAR treatment for TdR incorporation transitioned from PAR inhibition at the southernmost sampling areas to PAR stimulation at $13^{\circ} \mathrm{S}$. These data suggested that bacterial communities exposed to low intensities of solar irradiance were more susceptible to deleterious effects of sunlight than communities routinely exposed to higher intensities of UVR and PAR. The higher correlation between PAR treatment for TdR incorporation and daily-integrated PAR also suggested that photo-responses of bacterial communities during short-term experimental exposures were influenced by previous long-term exposure to ambient solar irradiance. Between $25^{\circ}$ and $13^{\circ} \mathrm{S}$, PAR-stimulated Leu incorporation declined, whereas PAR-stimulated TdR incorporation increased with increasing PAR exposure. These data are enigmatic, but suggest a shift in the metabolism of the bacterial community associated with latitudinal variation in solar irradiance.

Upwelling (Peeters et al. 2002) and the ${ }^{13} \mathrm{C}$ Suess Effect (Keeling 1979, Keeling et al. 2004) influence the distribution of $\delta^{13} \mathrm{C}_{\text {DIC }}$ in marine surface water. However, the robust correlation we observed between daily-integrated UVB and $\delta^{13} \mathrm{C}_{\text {DIC }}$ was unexpected. Our initial hypothesis was that $\delta^{13} \mathrm{C}_{\text {DIC }}$ would reflect the distribution of upwelling waters off the coast of Peru and at the equator. Our data suggest additional factors contribute to the decrease in $\delta^{13} \mathrm{C}_{\text {DIC }}$ in these waters. Baldwin et al. (2005) reported the distribution of sea surface temperatures, nitrate, chlorophyll, and bacteria across the Equatorial Upwelling zone at $\sim 165^{\circ} \mathrm{W}$. Sea surface temperatures were depressed and concentrations of nitrate, chlorophyll, and bacteria were elevated at the equator. Along the TABASCO cruise transect $\left(\sim 80^{\circ} \mathrm{W}\right)$, we did not observe these same trends across the equator. Fiedler et al. (1991) reported that surface currents in the far eastern Pacific were not divergent at the equator during August to November 1990, which suggested that upwelling was not well developed in the eastern Equatorial Pacific during this period. Equatorial surface water was also influenced by the ENSO cycle. TOPEX/Poseidon data collected during August 2000, however, indicated that the ENSO cycle had entered a neutral phase and did not show sea surface temperature anomalies suggestive of equatorial upwelling along the survey route (http://topex-www.jpl.nasa.gov/science/timeseries/ 200008_P.html). In the high nitrate water off the coast of Peru, there was no significant correlation between concentrations of nitrate and $\delta^{13} \mathrm{C}_{\mathrm{DIC}}$ values at the surface. Furthermore, the negative correlation between $\delta^{13} C_{\text {DIC }}$ and sea surface temperatures suggested that isotopically-light DIC was associated with warm water, rather than cooler waters, as might be expected if upwelling accounted for the distribution of $\delta^{13} C_{\text {DIC }}$ along this section of the survey.

Correlations between $\delta^{13} \mathrm{C}_{\mathrm{DIC}}$, solar irradiance, and Leu incorporation between $21^{\circ} \mathrm{S}$ and $3^{\circ} \mathrm{N}$ suggest that photolysis and photo-oxidation of DOC might influence the distribution of $\delta^{13} \mathrm{C}_{\mathrm{DIC}}$ in surface water. Bulk marine $\delta^{13} \mathrm{C}_{\mathrm{DOC}}$ range from -24 to $-22 \%$ and do not appear to vary appreciably with depth or season (Bauer et al. 2002). Photo-oxidation of DOC would deplete DIC in ${ }^{13} \mathrm{C}$. In Antarctic waters, UVB influences $\delta^{13} C_{\text {DIC }}$ during the austral spring. Karentz \& Spero (1995) reported that $\delta^{13} C_{\text {DIC }}$ in the Bellinghausen Sea, Antarctica, was positively correlated with total column ozone (TCO). Over $6 \mathrm{~d}$, total column ozone declined from $>350$ to $<200$ Dobson Units (DU) and surface $\delta^{13} \mathrm{C}_{\text {DIC }}$ declined from $\sim 1$ to $-2.3 \%$. The decline in $\delta^{13} \mathrm{C}_{\mathrm{DIC}}$ was attributed to the rapid remineralization of organic matter during periods of low TCO and elevated UVB. In our study, the lowest surface water $\delta^{13} C_{\text {DIC }}$ occurred in the zone of elevated UVB near the equator. Direct UVR-oxidation and photolysis and subsequent bacterial oxidation of recently upwelled DOC (Kieber et al. 1989, Benner \& Biddanda 1998, Miller \& Zepp 1995, Miller \& Moran 1997) might, in part, account for the spatial patterns we observed among $\delta^{13} \mathrm{C}_{\mathrm{DIC}}$, daily-integrated UVB, and dark incorporation of Leu between $13^{\circ}$ and $3^{\circ} \mathrm{S}$.

A significant quantity of organic carbon would have to be oxidized to account for the $\delta^{13} \mathrm{C}_{\mathrm{DIC}}$ distribution we observed along the survey. The difference in $\delta^{13} \mathrm{C}_{\text {DIC }}$ measured between $21^{\circ}$ and $3^{\circ} \mathrm{S}$ was $-2.07 \%$. To produce a $1 \%$-decrease in a $2 \mathrm{mM}$, DIC pool with an initial $\delta^{13} \mathrm{C}$ value of $0 \%$ would require the oxidation of $100 \mu \mathrm{M}$ of organic carbon with a $\delta^{13} \mathrm{C}$ value of $-22 \%$. DOC concentrations in Equatorial Pacific surface waters are $\sim 60$ to $70 \mu \mathrm{M}$ (Sharp et al. 1995) and $\sim 65 \mu \mathrm{M}$ in the Peruvian Upwelling (Archer et al. 1997). If photolysis and photo-oxidation of DOC were solely responsible for the changes in $\delta^{13} C_{\text {DIC }}$ that we observed, it would require the complete oxidation of the surface DOC pool over some unknown interval of time. Whereas rates of DOC photo-mineralization have been measured in temperate coastal waters ( 0.1 to $0.4 \mu \mathrm{mol}$ $\mathrm{C} \mathrm{m} \mathrm{l}^{-1} \mathrm{~h}^{-1}$, Miller \& Zepp 1995), photo-mineralization 
rates of DOC in tropical and subtropical pelagic waters are not known. Whether photo-oxidation of DOC is a significant component of the carbon cycle of the eastern tropical Pacific will require further investigation.

Latitudinal trends in dark treatment Leu and TdR incorporation in our deck experiments were quite different from trends in light treatment protein and nucleic acid synthesis and, unlike light treatment responses, did not appear to be closely related to shifts in community structure. Several other studies have observed differences in the effects of solar radiation on leucine and thymidine incorporation (Aas et al. 1996, Sommaruga et al. 1997, Pakulski et al. 1998). Much of our current understanding of bacterial production in the ocean is derived from Leu and TdR incorporation measurements performed in the dark. However, recent work (Aas et al. 1996, Pakulski et al. 1998, Morán et al. 2001, Church et al. 2004, Alonso-Sáez et al. 2006) and this study suggest that dark incubation measurements may seriously under or over-estimate in situ bacterial production in aquatic environments. Estimates of in situ bacterial production should therefore be conducted under ambient light conditions, including diurnal light treatment and nocturnal dark treatment measurements of Leu and TdR incorporation. It is apparent that light may have inhibitory or stimulatory effects on bacterial production. While very short incubations may reduce these effects on measurements, the kinetics of these responses remains largely unknown and warrant further investigation.

Acknowledgements. We thank the captain, crew, and Raytheon Polar Services personnel of the RVIB 'Nathaniel B. Palmer' for their assistance at sea. We also thank J. Macauley and the staff of the University of West Florida Wetlands Research Laboratory for nutrient analyses and the University of West Florida Center for Statistical Analysis for their assistance. We especially thank P. Penhale and National Science Foundation Office of Polar Programs for their efforts to facilitate our participation in this ship-of-opportunity cruise. This research was supported by grant OPP 9827319 to W.H.J. and grant OCE 9977040 to S.W.W.

\section{LITERATURE CITED}

Aas P, Lyons MM, Pledger RJ, Mitchell DL, Jeffrey WH (1996) Inhibition of bacterial activities by solar radiation in nearshore waters and the Gulf of Mexico. Aquat Microb Ecol 11:229-238

Alonso-Sáez L, Gasol JM, Lefort T, Hofer J, Sommaruga R (2006) Effect of natural sunlight on bacterial activity and differential sensitivity of natural bacterioplankton groups in northwestern Mediterranean coastal waters. Appl Environ Microbiol 72:5806-5813

Archer DE, Peltzer ET, Kirchman DL (1997) A timescale for dissolved organic carbon production in equatorial Pacific surface waters. Global Biogeochem Cycles 11:435-452

Azam F (1998) Microbial control of oceanic carbon flux: the plot thickens. Science 280:694-696

Baldwin AJ, Moss JA, Pakulski JD, Catala P, Joux F, Jeffrey WH (2005) Microbial diversity in a Pacific Ocean transect from the Arctic to Antarctic Circles. Aquat Microb Ecol 41: 91-102

Bauer JE, Druffel ERM, Wolgast DM, Griffin S (2002) Temporal and regional variability in sources and cycling of DOC and POC in the northwest Atlantic continental shelf and slope. Deep Sea Res 49:4387-4419

Béjà OL, Aravind EV, Koonin MT, Suzuki A and 7 others (2000) Bacterial rhodopsin: evidence for a new type of phototrophy in the sea. Science 289:1902-1906

Benner R, Biddanda B (1998) Photochemical transformations of surface and deep marine dissolved organic matter: effects on bacterial growth. Limnol Oceanogr 43: 1373-1378

Church MJ, Ducklow HW, Karl DM (2004) Light dependence of $\left[{ }^{3} \mathrm{H}\right]$ leucine incorporation in the oligotrophic North Pacific Ocean. Appl Environ Micobiol 70:4079-4087

Fiedler PC, Philbrick V, Chavez FP (1991) Ocean upwelling and productivity in the eastern tropical Pacific. Limnol Oceanogr 36:1834-1850

Goldman JC, Caron DA, Andersen OK, Dennett MR (1985) Nutrient cycling in a microflagellate food chain: I. Nitrogen dynamics. Mar Ecol Prog Ser 24:231-242

Harm W (1980) Biological effects of ultraviolet radiation. Cambridge University Press, Cambridge

Herndl GJ (1997) Role of ultraviolet radiation on bacterioplankton activity. In: Häder DP (ed) The effects of ozone depletion on aquatic ecosystems. Academic Press, New York, p 143-154

Herndl GJ, Müller-Niklas G, Frick J (1993) Major role of ultraviolet-B in controlling bacterioplankton growth in the surface layer of the ocean. Nature 361:717-719

Hut G (1987) Consultants group meeting on stable isotope reference samples for geochemical and hydrological investigations. Consultants Group Meeting IAEA, Report to the Director General, International Atomic Energy Agency, Vienna

Jeffrey WH, Kase JP, Wilhelm SW (2000) UV radiation effects on heterotrophic and viruses in marine ecosystems. In: DeMora S, Demers S, Vernet M (eds) The effects of UV radiation in the marine environment. Cambridge University Press, Cambridge, p 206-236

Karentz D, Spero HJ (1995) Response of a natural Phaeocystis population to ambient fluctuations in UVB radiation caused by Antarctic ozone depletion. J Plankton Res 17: 1771-1789

Keeling CD (1979) The Suess Effect: ${ }^{13}$ Carbon $-{ }^{14}$ Carbon interrelations. Environ Int 2:229-300

Keeling CD, Brix H, Gruber N (2004) Seasonal and long-term dynamics of the upper ocean carbon cycle at Station ALOHA near Hawaii. Glob Biogeochem Cycles 18:GB4006, doi:10.1029/2004GB002227

Kieber DJ (2000) Photochemical production of biological substrates. In: DeMora S, Demers S, Vernet M (eds) The effects of UV radiation in the marine environment. Cambridge University Press, Cambridge, p 130-148

Kieber DJ, McDaniel J, Mopper K (1989) Photochemical source of biological substrates in seawater, implications for carbon cycling. Nature 341:637-639

Kolber ZS, Plumley FG, Lang AS, Beatty JT and 6 others (2001) Contribution of aerobic photoheterotrophic bacteria to the carbon cycle in the ocean. Science 292: 2492-2495

Kornberg A (1980) DNA replication. WH Freeman, San Francisco 
Marañón E, Cermeño P, Fernández E, Rodríguez J, Zabala L (2004) Significance and mechanisms of photosynthetic production of dissolved organic matter in a coastal eutrophic ecosystem. Limnol Oceanogr 49:1652-1666

Miller WL, Moran MA (1997) Interaction of photochemical and microbial processes in the degradation of refractory dissolved organic matter from a coastal marine environment. Limnol Oceanogr 42:1317-1324

Miller WL, Zepp RG (1995) Photochemical production of dissolved inorganic carbon from terrestrial organic matter: significance to the oceanic organic carbon cycle. Geophys Res Lett 22:417-420

Moran MA, Zepp RG (2000) UV radiation effects on microbes and microbial processes. In: Kirchman DL (ed) Microbial ecology of the oceans. Wiley-Liss, New York, p 201-228

Morán XAG, Massana R, Gasol JM (2001) Light conditions affect the measurement of oceanic bacterial production via leucine uptake. Appl Environ Microbiol 67:3795-3801

Murray AE, Preston CM, Massana R, Taylor LT, Blakis A, Wu K, DeLong EF (1998) Seasonal and spatial variability of bacterial and archaeal assemblages in the coastal waters near Anvers Island, Antarctica. Appl Environ Microbiol 64:2585-2595

Muyzer GE, De Waal C, Uitterlinden AG (1993) Profiling of complex microbial populations by denaturing gradient gel electrophoresis analysis of polymerase chain reactionamplified genes coding for 16S rRNA. Appl Environ Microbiol 59:695-700

Neefs J, Van de Peer Y, Hendriks L, De Wachter R (1990) Compilation of small ribosomal subunit RNA sequences. Nucleic Acids Res 18:2237-2242

Ögrünç M, Becker DF, Ragsdale SW, Sancar A (1998) Nucleotide excision repair in the third kingdom. J Bacteriol 180:5796-5798

Pakulski JD, Aas P, Jeffrey WH, Lyons M, Von Waasenbergen L, Mitchell D, Coffin R (1998) Influence of light on bacterioplankton production and respiration in a subtropical reef. Aquat Microb Ecol 14:137-148

Peeters FJC, Brummer GJA, Ganssen G (2002) The effect of upwelling on the distribution and stable isotope composition of Globigerina bulloides and Globigerinoides ruber (planktic foraminifera) in modern surface waters of the NW Arabian Sea. Deep-Sea Res 49:1485-1505

Pomeroy LR, Wiebe WJ (2001) Temperature and substrates as interactive limiting factors for marine heterotrophic bacteria. Aquat Microb Ecol 23:187-204

Porter KG, Feig YS (1980) The use of DAPI for identifying and counting aquatic microflora. Limnol Oceanogr 25:243-248

Sharp JH, Benner R, Bennett L, Carlson CA, Fitzwater SE, Peltzer ET, Tupas LM (1995) Analyses of dissolved organic carbon in seawater: the JGOFS EqPac methods comparison. Mar Chem 48:91-108

Smith DC, Azam F (1992) A simple, economical method for measuring bacterial protein synthesis rates in seawater

Editorial responsibility: Ruben Sommaruga, Innsbruck, Austria using ${ }^{3}$ H-leucine. Mar Microb Food Webs 6:107-114

Sommaruga R, Oberleiter A, Pennser R (1996) Effect of UV radiation on bacterivory of a heterotrophic nanoflagellate. Appl Environ Microbiol 62:4395-4400

Sommaruga R, Obernosterer I, Herndl GJ, Psenner R (1997) Inhibitory effect of solar radiation on thymidine and leucine incorporation by freshwater and marine bacterioplankton. Appl Environ Microbiol 63:4178-4184

Strom SL (2000) Bacterivory: Interactions between bacteria and their grazers, In: Kirchman DL (ed) Microbial ecology of the oceans. John Wiley \& Sons, New York, p 351-386

Sverdrup HU (1953) On conditions for the vernal blooming of phytoplankton. J Cons Perm Int Exp Mar 18:287-295

Thingstad TF, Skjoldal, EF, Bohne RA (1993) Phosphorous cycling and algal-bacterial competition in Sandsfjord, western Norway. Mar Ecol Prog Ser 99:239-259

Tortell PD, Maldonado MT, Granger J, Price NM (1999) Marine bacteria and biogeochemical cycling of iron in the oceans. FEMS Microbiol Ecol 29:1-11

US Environmental Protection Agency (1983) Methods for chemical analysis of water and wastes. USEPA Office of Research and Development, Washington, DC, Document EPA/600/4-79/020

Van Mooy BAS, Devol AH, Keil RG (2004) Relationship between bacterial community structure, light and carbon cycling in the eastern subarctic North Pacific. Limnol Oceanogr 49:1056-1062

Vincent WF, Neale P (2000) Mechanisms of UV damage to aquatic organisms. In: DeMora $S$, Demers $S$, Vernet $M$ (eds) The effects of UV radiation in the marine environment. Cambridge University Press, Cambridge, p 149-176

Welschmeyer NA (1994) Fluormetric analysis of chlorophyll a in the presence of chlorophyll $b$ and pheopigments. Limnol Oceanogr 35:1985-1992

Whitehead RF, de Mora, SJ Demers S (2000) Enhanced UV radiation - a new problem for the marine environment. In: DeMora S, Demers S, Vernet M (eds) The effects of UV radiation in the marine environment. Cambridge University Press, Cambridge, p 1-34

Wilhelm SW, Weinbauer MG, Suttle CA, Jeffrey WH (1998) The role of sunlight in the removal and repair of viruses in the sea. Limnol Oceanogr 43:586-592

Wilhelm SW, Jeffrey WH, Dean AL, Meador J, Pakulski JD, Mitchell DL (2003) UV radiation induced DNA damage in marine viruses along a latitudinal gradient in the southeastern Pacific Ocean. Aquat Microb Ecol 31:1-8

Zlotnik I, Dubinsky Z (1989) The effect of light and temperature on DOC excretion by phytoplankton. Limnol Oceanogr 34:831-839

Zubkov MV, Fuchs BM, Tarran GA, Burkill PH, Amann R (2003) High rate of uptake of organic nitrogen compounds by Prochlorococcus cyanobacteria as a key to their dominance in oligotrophic oceanic waters. Appl Environ Microbiol 69:1299-1304

Submitted: October 30, 2006; Accepted: March 8, 2007

Proofs received from author(s): April 28, 2007 